\title{
PENERAPAN MODEL PROBLEM BASE LEARNING UNTUK MENINGKATKAN HASIL BELAJAR MATEMATIKA MATERI MATRIKS PADA SISWA KELAS X OTKP-1 SMK NEGERI 1 SIGLI
}

\author{
Nasrina \\ SMA Negeri 1 Sigli
}

\begin{abstract}
ABSTRAK
Penerapan Model Problem Base Learning Untuk Meningkatkan Hasil Belajar Matematika Materi Matriks Pada Siswa Kelas X OTKP-1 SMK Negeri 1 Sigli . Penelitian ini dilakukan di SMK Negeri 1 Sigli selama tiga bulan sejak bulan Januari sampai Maret 2021 bertujuan untuk meningkatkan hasil belajar matematika materi matriks dengan menerapkan model problem base learning pada siswa kelas X OTKP-1 SMK Negeri 1 Sigli. Metode penelitian yang digunakan adalah penelitian tindakan kelas (PTK) yang terdiri atas 2 siklus. Subyek penelitian adalah siswasiswi Kelas X OTKP-1 SMK Negeri 1 Sigli tahun pelajaran 2020/2021 sebanyak 29 siswa. Analisis data menggunakan teknik analisis deskriptif komparatif dengan membandingkan kondisi awal dengan hasil-hasil yang dicapai pada setiap siklus, dan analisis deskriptif kualitatif hasil observasi dengan membandingkan hasil observasi dan refleksi pada siklus I dan siklus 2. Hasil yang diperoleh dengan menerapkan model problem base learning dalam materi matriks bagi siswa kelas X OTKP-1 pada SMK Negeri 1 Sigli adalah hasil tes pada siklus I dengan persentase ketuntasan sebesar 65,5\%, nilai rata-rata kelas sebesar 74,9 dan meningkat pada hasil tes siklus II sebesar $89,7 \%$ dengan nilai rata-rata kelas 84 . Pada kedua siklus ini terjadi perubahan aktifitas siswa dan perolehan nilai yang signifikan bila dibandingkan dengan kondisi awal sebelum dilakukannya tindakan kelas.
\end{abstract}

Kata Kunci : Hasil Belajar, Model Problem Base Learning, Matriks

\section{PENDAHULUAN}

Matematika merupakan pelajaran yang dianggap sulit dan tidak disukai oleh siswa, terutama materi matriks. Oleh karena itu hasil pembelajaran matematika tidak sesuai dengan yang diharapkan.

Berdasarkan hasil ulangan harian siswa kelas X OTKP-1 SMK Negeri 1 Sigli, dari jumlah siswa sebanyak 29 orang, hanya 12 orang siswa atau $41,4 \%$ yang memperoleh ketuntasan belajar. Sedangkan 17 orang atau $58,6 \%$ siswa memperoleh nilai di bawah KKM (Kriteria Ketuntasan Minimal).

Salah satu penyebab kondisi di atas adalah penggunaan strategi pembelajaran yang kurang tepat, yang masih mengenyampingkan aktivitas belajar dan mengabaikan kemampuan memecahkan masalah matematika siswa. Oleh karena itu, salah satu langkah yang bisa dilakukan oleh guru sebagai pembimbing peserta didik adalah memilih strategi pembelajaran yang lebih tepat, yang mampu mengembangkan aktivitas dan kemampuan memecahkan masalah matematika siswa.

Mengingat pentingnya aktivitas siswa dalam pembelajaran matematika sehingga mampu meningkatkan kemampuan memecahkan masalah matematika siswa khususnya matriks, maka diperlukan suatu pendekatan pembelajaran yang mampu mengembangkan aktivitas dan kemampuan 
memecahkan masalah matematika siswa. Salah satu strategi pembelajaran yang saat ini sedang berkembang dan mampu mengembangkan aktivitas dan kemampuan memecahkan masalah matematika siswa adalah strategi problem base learning (problem based learning), denagn tujuan agar dapat meningkatkan hasil belajar matematika materi matriks pada siswa kelas X OTKP-1 SMK Negeri 1 Sigli.

\section{TINJAUAN PUSTAKA}

Slameto (2003) mengatakan: "belajar adalah suatu proses yang dilakukan individu untuk memperoleh perubahan tingkah laku yang baru secara keseluruhan". Perubahan tingkah laku itu akan didapat melalui berbagai hasil pengalaman individu itu sendiri dalam interaksi dengan lingkungannya. Sementara untuk hasil belajar Sutrisno (2006) menyatakan bahwa hasil belajar merupakan sesuatu yang diperoleh dari dan sesudah kegiatan pembelajaran berlangsung. Banyak faktor yang dapat mempengaruhi hasil belajar seperti yang dikemukakan oleh Slameto (2003) adalah : "Faktor-faktor yang mempengaruhi hasil belajar banyak jenisnya, tetapi dapat digolongkan menjadi dua golongan saja, yaitu faktor intern dan faktor ekstern. Faktor intern adalah faktor yang ada dalam diri individu yang sedang belajar, sedangkan faktor ekstern adalah faktor yang ada di luar individu."

Salah satu faktor ekstern adalah seperti penggunaan model pembelajaran yang digunakan guru untuk mencapai tujuan pembelajaran itu sendiri. Penggunaan metode dan model pebelajaran yang kurang tepat dapat mengakibatkan rendahnya hasil pembelajaran. Ratnaningsih (dalam Trihardiayanti, 2008) mengatakan bahwa : "model problem base learning merupakan suatu aktivitas mental siswa untuk memahami suatu konsep pembelajaran melalui situasi dan masalah yang disajikan pada awal pembelajaran".

\section{METODOLOGI PENELITIAN}

Penelitian dilaksanakan di SMK Negeri 1 Sigli di kelas X OTKP-1 pada materi matriks selama 3 bulan yaitu pada bulan Januari s/d Maret 2021.

Subjek penelitian adalah siswa-siswi kelas X OTKP-1 tahun pelajaran 2020/2021 dengan jumlah siswa sebanyak 29 orang. Data yang diperoleh berasal dari siswa kelas $X$ OTKP-1 SMK Negeri 1 Sigli dan guru/teman sejawat yang merupakan guru kolaborasi dalam melaksanakan kegiatan penelitian ini.

Teknik pengumpulan data yang dilakukan dengan observasi dan tes. Alat pengumpulan data yang digunakan adalah: Lembar instrument aktifitas siswa dalam PBM, Lembar intrumen PBM guru dan butir soal test. Analisis data yang digunakan adalah analisis deskriptif.

Dalam penelitian ini menggunakan dan mengembangkan siklus yang mengandung empat komponen yaitu: rencana tindakan (planning), (2) pelaksanaan (action), (3) observasi (observation), (4) refleksi (reflection).

\section{HASIL PEMBAHASAN}

Berdasarkan hasil pengamatan pada siklus I dan siklus II mengalami peningkatan hasil belajar dan juga aktivitas baik bagi guru maupun bagi siswa dalam kegiatan belajar mengajar dan mencapai ketuntasan. Hasil tes pada siklus I dengan persentase ketuntasan sebesar $65,5 \%$, nilai rata-rata kelas sebesar 74,9 dan hasil tes siklus II sebesar $89,7 \%$ dengan nilai rata-rata kelas 84 . Maka terlihat bahwa nilai siswa telah mencapai standar ketuntasan secara klasikal pada siklus II yaitu $\geq 85 \%$. Mulyana (2005:99) menyatakan. "keberhasilan kelas dilihat dari jumlah peserta didik yang mampu menyelesaikan atau mencapai sekurang-kurangnya $85 \%$ dari jumlah peserta didik yang ada di kelas tersebut. Dengan demikian dapat disimpulkan terdapat peningkatan hasil 
belajar siswa selama dua siklus dan telah tuntas secara klasikal pada materi matriks dengan menggunakan model problem base learning. Hal ini disebabkan adanya peningkatan interaksi yang terjadi sehingga mengakibatkan efek yang positif terhadap pemahaman siswa dalam mempelajari materi ajar. Hasil tes pada siklus I dan II berbeda dengan hasil tes pra siklus dengan perolehan nilai rata-rata kelas adalah 64,9 dan ketuntasan siswa yang dicapai hanya 41,4\%.

Hasil Belajar Siswa secara gabungan mulai pra siklus, siklus I dan siklus II dapat dilihat pada tabel dan grafik berikut:

\begin{tabular}{|c|c|c|c|c|c|c|c|}
\hline \multirow{2}{*}{ No } & \multirow{2}{*}{ Ketuntasan } & \multicolumn{2}{|c|}{$\begin{array}{c}\text { Pra } \\
\text { Siklus }\end{array}$} & \multicolumn{2}{|c|}{ Siklus I } & \multicolumn{2}{|c|}{ Siklus II } \\
\hline & & Jlh & $\%$ & Jlh & $\%$ & Jlh & $\%$ \\
\hline 1. & Tuntas & 12 & 41,4 & 19 & 65,5 & 26 & 89,7 \\
\hline 2. & Tidak Tuntas & 17 & 58,6 & 10 & 34,5 & 3 & 10,3 \\
\hline \multicolumn{2}{|c|}{ Jumlah Siswa } & \multicolumn{2}{|c|}{29} & \multicolumn{2}{|c|}{29} & \multicolumn{2}{|c|}{29} \\
\hline \multicolumn{2}{|c|}{ Rata-Rata Kelas } & \multicolumn{2}{|c|}{64,9} & \multicolumn{2}{|c|}{74,9} & \multicolumn{2}{|c|}{84} \\
\hline
\end{tabular}

Keterangan : Nilai KKM 70

\section{HASIL BELAJAR SISWA}

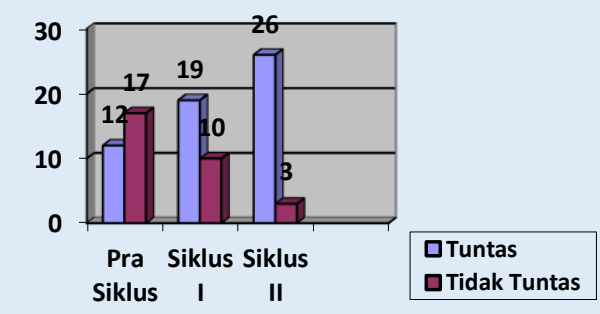

\section{KESIMPULAN}

Hasil perolehan pada siklus I dengan persentase ketuntasan sebesar $65,5 \%$ nilai rata-rata kelas sebesar 74,9 dan meningkat pada hasil tes siklus II sebesar $89,7 \%$ dengan nilai rata-rata kelas 84. Pada kedua siklus ini terjadi perubahan aktifitas dan perolehan nilai yang signifikan bila dibandingkan dengan pra siklus dengan ketuntasan belajar yang hanya mencapai $41,4 \%$ siswa.

Adapun hasil pengamatan pada proses belajar mengajar menunjukkan aktivitas siswa lebih meningkat selama proses pembelajaran berlangsung, baik pada siklus I maupun pada siklus II dibandingkan dengan suasana belajar siswa yang pasif dan kaku sebelum dilakukannya tindakan kelas. Perolehan persentase keaktifan siswa pada siklus I adalah $38,18 \%$ dan pada siklus II adalah 61,25\%. Aktivitas guru juga meningkat pada siklus I dan siklus II dalam hal penggunaan metode dengan perolehan persentase skor adalah $43,75 \%$ dengan kategori cukup menjadi $81,8 \%$ pada siklus II dengan kategori baik.

Berdasarkan hasil penelitian ini dapat disimpulkan bahwa dengan menerapkan model problem base learning dapat meningkatkan hasil belajar matematika materi matriks pada siswa kelas X OTKP-1 SMK Negeri 1 Sigli.

Diharapkan kepada para guru dapat menggunakan model problem base learning pada materi bahasan lainnya yang berhubungan dengan peristiwa sehari-hari, sehingga konsep-konsep matematika tidak mudah terlupakan.

\section{DAFTAR PUSTAKA}

Anas Sudijono. 2005. Pengantar Evaluasi Pendidikan. Jakarta : PT. Raja Grafindo Persada.

Aqib, Zainal, 2009. Penelitian Tindakan Kelas untuk Guru. Bandung: Yrama Widya.

Daryanto, 2009. Panduan Proses Pembelajaran Kreatif \& Inovatif. Jakarta: Publisher.

Hamalik, Oemar. 2001. Proses Belajar Mengajar. Jakarta : Bumi Aksara.

Hamalik, Oemar. 2008. Kurikulum dan Pembelajaran. Jakarta : Bumi Aksara. 
Jurnal Sains Riset (JSR)

p-ISSN 2088-0952, e-ISSN 2714-531X

http://journal.unigha.ac.id/index.php/JSR

DOI. $10.47647 /$ jsr.v10i12

Slameto. 2003 . Belajar dan Faktor-faktor yang Mempengaruhinya. Bandung: PT. Rineka Cipta.

Sumadi. 2002. Prestasi dalam Belajar. Jakarta : Pustaka Widyamara.

Supariasa, I.D.N. 2012. Penilaian Status Gizi. Jakarta: EGC.
Wina Sanjaya. 2008. Belajar dan FaktorFaktor Yang Mempengaruhinya. Rineka Cipta; Jakarta.

Winkel, WS 1997. Psikologi Pendidikan dan Evaluasi Belajar. Jakarta : Gramedia 